\title{
Corporate Social Responsibility Disclosures in Nigeria: A Study of Listed Financial and Non-Financial Firms
}

\author{
Uwalomwa Uwuigbe (Corresponding author) \\ $\mathrm{PhD}$, Dept. Of Accounting, College Of Development Studies \\ Covenant University, Ota, Ogun State, Nigeria \\ E-mail: alaiwu2003@yahoo.com \\ Ben-Caleb Egbide \\ Dept. Of Accounting, College Of Development Studies \\ Covenant University, Ota, Ogun State, Nigeria \\ E-mail: ben-caleb1@yahoo.com
}

Received: August 17, 2011 Accepted: October 17, $2011 \quad$ Published: March 1, 2012

doi:10.5539/jms.v2n1p160 URL: http://dx.doi.org/10.5539/jms.v2n1p160

\begin{abstract}
This study is an empirical investigation of the relationship between firms' corporate financial performance and the level of corporate social responsibility disclosures among selected firms in Nigeria. It also looked at the relationship between firms' financial leverage and the level of corporate social responsibility disclosures among selected firms. While the annual reports for the period 2008 was utilized as the main source of data collection for the sampled 41 listed firms, the multiple regression analysis was employed as a statistical technique for analysing the data collected. The paper revealed that firms' corporate financial performance and the size of audit firm have a significant positive relationship with the level of corporate social responsibility disclosures among selected firms. Also, the paper as part of its findings- observed that a significant negative relationship existed between firms' financial leverage and the level of corporate social responsibility disclosures. The paper therefore recommends that government, as part of their responsibility, should put in place policies that will create a good business environment for firms operating in the country.
\end{abstract}

Keywords: Financial performance, Annual reports, Firms, Corporate, Social, Environmental responsibility

\section{Introduction}

The awareness of the environment and man's ability to cause damage started from the fifties of last Century. In 1972, a world conference was held in Stockholm where heads of States from all over the world came together for the first time to consider the state of the globe as a whole, which ultimately gave birth to a special UN Agency titled UN Environmental Program (UNEP) to deal with environmental issues. In the mid-eighties, the World Commission on Environment and Development (WCED), known as Bruntdland Commission, was established by the UN. The Commission published a report, called Our Common Future in 1987, with the proposed concept of 'sustainable development'. This concept received worldwide acceptance and led to the convening of the UN Conference on Environment and Development (UNCED) in Rio de Janerio, Brazil in 1992, known as "EARTH SUMMIT". In this conference, heads of different States signed four agreed document including the Agenda 21. The Agenda 21 contains a checklist of do's and don'ts to protect the environment through the next Century. Particularly, the role of corporate entities in respect of overall management of the environment has been duly recognized in this conference.

Over the past decade, Nigeria has witnessed tremendous economic and social changes. As a result, the business environment is also becoming more complex and demanding. One of the emerging issues that confront modern-day businesses is that of corporate social responsibility. However, due to the heightened interest in the concept of corporate social responsibility and what it entails, much research has been done in this area, particularly in the developed countries. In contrast, the developing countries are slower in responding to the increased concern about the issue of corporate social responsibility. Despite some intense research (Guobadia, 
2000; Hjalte and Larsson, 2003; Ite, 2004 and Amaeshi, Adi, Ogbechie and Amao, 2006; Belal, 2001; Imam, 2000; and Tsang, 1998), studies in this area in the developing countries are still scarce. To this end therefore, this study attempts to address this gap in literature by examining whether there is a significant relationship between firms attributes (financial performance, financial leverage and size of audit firms) and the level of corporate social responsibility disclosures of the selected firms in the Nigeria stock exchange.

The remaining part of this study is structured as follows: following the objective and the research hypothesis is the theoretical framework and the literature review for the study. The next section unfolds the methodology and presents the econometric model and preliminary empirical evidence. Finally, the last section summarizes the main findings of the study with discussion of implications for future research.

\subsection{Scope of study}

To achieve the objectives of this study, the paper basically focused on firms listed in the floor of the Nigerian Stock Exchange. The preference for these firms is motivated by the fact that their annual reports are easily accessible and capable for comparison. Nonetheless, using the judgmental sampling technique, a total of 41 firms (both in the financial and non-financial firms) were selected for this study (see appendix). In addition, the choice for these firms is based on the nature of their production; direct financial services provided some financial institutions, nature of disposal of wastages, environmental pollution and their market capitalization composition ranking for July, 2009.

\subsection{The Nigerian context}

Nigeria, being one of the world largest producers of crude oil to some extent, has experienced some rapid economic and technological development that has, in turn brought about higher levels of education, better standards of living and greater affluence amongst Nigerians. This better economic position has also meant higher levels of education amongst its people. Consequently, of late, there appears to be increased public concern and awareness for corporate social environmental impact. This could also be due to the prominent role played by the non-governmental organizations (NGOs), such as the green alliance Nigeria, and the Federal Environmental Protection Agency (FEPA) of Nigeria, in lobbying for the preservation and conservation of the environment. The intense media scrutiny and coverage of environmental problems - including cases of open continuous gas flaring, environmental degradation in the Niger-Delta regions, burning, indiscriminate land and hill clearing, and toxic waste dumping- have also contributed to public concern for the detrimental effects of business operations on our natural environment. Due to this change in public concern and awareness on environmental issues, it may be the case then that companies in Nigeria must respond to such changes by providing environmental disclosures within the annual reports. As Wilmshurst and Frost (2000:12), argued that "If the members of the community are becoming more interested in the environmental impact of companies, it is likely that the senior management will be called on to explain the company's activities affecting the environment. Such accessibility may be promoted through disclosure within the annual report." To this end, this study seeks to find out whether there is a significant relationship between firms attributes and the level of corporate social responsibility disclosures of the selected listed firms.

\section{Literature review}

Corporate social disclosures have been the focus of much academic research since the mid - 1970's (Ahmad, Sulaiman, and Siswantoro, 2008, Minga, 2010). The popularity of this strand of research may be attributed to the apparent increasing recognition within the business community of the importance major stakeholders attach to socially and environmentally responsible corporate behavior (Zadek, 1998). Corporate environmental disclosures have been defined by a number of researchers. Deegan and Rankin (1996:51), for example described is as disclosures relating to the interaction between an organization and its physical and social environment inclusive of disclosures relating to human resources, community involvement, the natural environment, energy, and product safety. Though numerous empirical studies have been undertaken to examine the content of annual reports for corporate environmental disclosures, many of these studies have examined this issue in the developed West, indicatively referred in countries such as the U.S, Canada, U.K, Australia and Western Europe (Ernst and Ernst, 1978; Guthrie and Parker, 1990). Very few studies have examined corporate environmental disclosure practices in the developing countries, such as Bangladesh, Jordan, Malaysia and Singapore (Belal, 2001; Abu-Baker and Naser, 2000; and Tsang, 1998); and even then many of these studies are now outdated.

Nonetheless, most previous researchers from developed economies that have investigated the effect of the company size - as indicated by firm's assets and paid-up share capital on CSR disclosure - have suggested a positive correlation between size and social disclosure. Spicer (1978) suggests firm size as a factor influencing pollution control, as larger companies performed a better record in this regard than smaller firms. Watts and 
Zimmerman (1978) argued that because political costs reduce management wealth, companies attempt to reduce costs by such devices as social disclosure campaigns. Cowen, Ferreri and Parker (1987) found out that larger corporations tends to disclose more information because larger corporations are highly visible, make greater impact to the society, and have more shareholders who might be concerned with social activities undertaken by corporations. Other studies with similar findings include: Trotman and Bradley (1981); Ullmann, 1985; Hackston and Milne (1996) and Sarumpaet, 2005; concluded that size is an explanatory variable, insomuch as their findings indicated that firms supplying information on social responsibility are of a larger size, are more concerned with longer-term events, and have a positive systematic risk. However, the findings of the above studies are contradicted by environmental disclosure. Halme and Huse (1997) conducted a study on annual report for the year 1992 from Scandinavian countries (for example Sweden, Finland, Spain and Norway) found no significant relationship between environmental reporting and companies' size.

Research in the developing countries has generally observed that the extent of corporate environmental disclosures in annual reports is lower than in the developed countries. Savage (1994) examined the corporate social responsibility disclosure practices of 115 companies in South Africa. He found that as many as 50 percent of the companies had shown some CSR disclosures, with human resource disclosures being the most popular. This is closely followed by disclosures on community involvement and environmental performance. Despite the findings, Savage opined that the extent of CSR disclosure have remained predominantly low. In the Nigerian content, the conclusions derived from existing prior studies are contradicting. Amaeshi et.al, (2006) looked at corporate social responsibility in Nigeria a western mimicry of indigenous practices. They explored four key sectors of the Nigerian economy and came up with the conclusion that firms are socially constructed and their behaviour must reflect on the society in which they are embedded and thus must have to be socially responsible to the environment in which it operates. Also, Ngwakwe (2009) in his study titled environmental responsibility and firms' performance in Nigeria; investigated the relationship between firms social responsibility practices and their performance. The study while focusing only on the manufacturing industry concluded that a positive relationship exist between the social responsibility practice of firms and their performance. In addition, prior studies by Guobadia, 2000; Worgu, 2000; Minga, 2010 also reported a similar finding on the state of corporate social responsibility in Nigeria.

Consequently, due to the difference in methodology and the scope, it is difficult to compare the findings of these studies. Also, in addition to the increasing pressure from stakeholders arising from the increasing levels of education and heightened awareness on issues related to the social and environmental responsibility; neither of these studies attempted to address the issue of size as it impact on the level of corporate social responsibility. To this end therefore, this study intends to fill this gap in literature by examining the relationship between the financial performance of firms and the level of corporate environmental disclosure among selected listed firms in Nigeria.

\section{Methodology}

\subsection{Research hypotheses}

To achieve the objective of this study, the following hypotheses are stated in their null form:

$\mathbf{H}_{1}$ : there is no significant relationship between firms' corporate financial performance and the level of corporate social responsibility disclosures among selected firms.

$\mathbf{H}_{2}$ : there is no significant relationship between the firms' financial leverage and the level of corporate social responsibility disclosures among selected firms.

$\mathbf{H}_{3}$ : there is a significant relationship between the size of audit firm and the level of corporate social responsibility disclosures among selected firms.

\subsection{Research methodology}

The main purpose of this paper is to find out whether there is a significant relationship between firms' corporate financial performance and the level of environmental disclosures, among listed firms in Nigeria. To achieve this objective, the study has adopted the use of corporate annual reports of listed firms as our main source of data. This is due to the fact that annual reports are readily available and accessible. According to Gray, Kouhy, and Lavers (1995), annual reports should be used in determing environmental disclosures because such information is produced regularly and will be in the public domain. The annual reports for the period 2008-2009 will be used due to increased interest and the high level of awareness and pressure from stakeholders within these periods. To achieve this objective the content analysis method of data analysis will be used in eliciting data from the annual report. This is due to the fact that the content analysis method is the most commonly used method of measuring 
corporate social environmental disclosure in annual reports (Milne and Adler, 1999; Krippendorf, 1980). In addition, it allows corporate social environmental information to be systematically be classified and compared.

However, this study attempts to measure the corporate social responsibility disclosure in terms of themes and evidence, using Hackston and Milne's (1996) operational definitions and framework for corporate environmental disclosure index. Theme is measured in the categories of environment, energy, product, community, and employee health. Evidence is measured in the categories of monetary quantitative and non-monetary quantitative disclosures. The corporate environmental disclosure index framework contained 28 attributes. Consequently, a firm could score a maximum of 28 points and a minimum of 0 . The formula for calculating the reporting scores by using the corporate social environmental disclosure index (attributes) is expressed in a function form:

$$
\mathrm{RS}=\sum_{\mathrm{i}=1}^{28} \mathrm{~d}_{\mathrm{i}}
$$

Where:

RS = Reporting Score

$\mathrm{d}_{\mathrm{i}}=1$ if the item is reported; 0 if the item is not reported

$\mathrm{i} \quad=1,2,3 \ldots 28$

\subsection{Measurement of financial performance}

Although one might have expected a certain diversity of measures of corporate social environmental disclosures, there is no real consensus on the proper measures of corporate financial performance either. However, most measures of financial performance fall into three broad categories: investor based, accounting based; and the market based measures. Nevertheless, following the precedent of most of the previous studies of this nature, the study used of accounting based data as a proxy for financial performance. The choice preference for this method arises because it has enjoyed periods of popularity and has evolved considerably over the course of the past decade. Therefore, for the purpose of this study, financial performance will be measured by return on total assets (ROTA), which is the profit before interest and tax divided by the total assets. On the other hand, financial leverage will be measured by firms' debt to equity ratio. Consequently, measuring the relationship between the dependent and the independent variables, a linear regression model will be adopted, as shown below in functional form:

$$
\mathrm{CSRD}=\mathrm{f}\left(\mathrm{ROTA}_{\mathrm{t}}, \mathrm{DE}_{\mathrm{t}}, \mathrm{AUD}_{\mathrm{t}}\right)
$$

This can be written in explicit form as:

$$
\mathrm{CSRD}=\beta_{0}+\beta_{1} \mathrm{ROTA}_{\mathrm{t}}+\beta_{2} \mathrm{DE}_{\mathrm{t}}+\beta_{3} \mathrm{AUD}_{\mathrm{t}}+\mathrm{U}
$$

Where:

$\mathrm{CSRD}=$ Corporate Social Responsibility Disclosure.

ROTA $=$ Return on total assets as one of the proxy for performance is defined as the profit before interest and tax divided by total assets as at the end of the fiscal year under consideration.

$\mathrm{DE}=$ Debt to equity ratio, which is also a performance proxy representing the nature of the industry. It is defined as the total debt divided by the total equity.

$\mathrm{U}=$ Stochastic or disturbance term.

$\mathrm{t}=$ Time dimension of the Variables.

$\beta_{0}=$ Constant or Intercept.

$\beta_{1-3}=$ Coefficients to be estimated or the Coefficients of slope parameters.

\section{Findings and discussion}

Table 2 presents the Pearson correlation analysis result on the association between firms' corporate financial performance and the level of corporate social responsibility disclosures. It also indicates the association between the firms' financial leverage, size of audit firm and the level of corporate social responsibility disclosures among the selected listed firms. Analysis of the statistical results as depicted in Table 2 reveal that there is a significant positive association between firms' corporate financial performance (proxied by returns on total assets) and the level of corporate social responsibility disclosures among the selected listed firms. This result implies that the higher the operating profit or returns on the total assets of a firm the more they will be willing to put into consideration issues of corporate social responsibility. In essence, the higher the financial performance of firms, 
the more they will be willing to devote to financial resources for the development of a sustainable environment in which they operate. Similarly, Table 2 also shows that a significant positive association does exist between the size of audit firm and the level of corporate social responsibility disclosures. This result invariably implies that firms audited by big and prominent auditing firms tend to disclose more corporate social responsibility information than companies audited by small auditing firms. That is, firms audited by big auditing firms with international affiliations (such as the KPMG, the PricewaterhouseCoopers and the Akintola Williams Deloitte) tend to have a significantly higher level of corporate social disclosure than others that are audited by small local audit firms. This result could be due to the fact that these audit firms follow internal procedures and control that are required by international auditing standards. On the other hand, a significant negative association was observed between firms' financial leverage and the level of corporate social responsibility disclosures among the selected listed firms. This finding invariably portends that firms with high debt profile and a higher risk of insolvency would be unwilling to devote extra cost on corporate environmental issues.

Furthermore, using the ordinary least square (OLS) regression model for all the variables as presented in Table 3 shows that the multiple regression model is significant with a $\mathrm{p}<005$. The adjusted coefficient of determination (R-squared) indicates that about $59 \%$ of the variation in the dependent variable is explained by the variations in the independent variables. This indicates clearly that simultaneously the explanatory variables altogether are very significantly associated with the dependent variable. More so, a marathon review of the of the multiple regression analysis results as presented in Tables 4 and 5 indicates that consistent with our a priori expectation, a significant positive relationship does exist between the financial performance of firms' and the level of corporate social responsibility disclosures with a t-statistics value of $(4.531$ and a p-value $<.005)$. This outcome corroborates or confirms the findings provided by Mohamed, Zain and Tamoi (2006). Similarly, a significant positive association was observed between the size of audit firm and the level of corporate social responsibility disclosures among the selected listed firms. This outcome is however in line with the findings provided in Dahawy (2009) and Janggu, Joseph \& Madi (2007). Nonetheless, the results in Table 5 further reveal that consistent with the findings of both Mohamed and Ahmed (2001); Trotman and Bradley (1981) a significant negative relationship does exist between firms' financial leverage and the level of corporate social responsibility disclosures among the selected firms with a t-statistics value of -2.443 and a p-value $<.005$. This result in a nutshell invariably implies that firms' with high debt profile and a higher risk of insolvency would be unwilling to devote extra cost on corporate environmental issues. This means that the higher the financial indebtedness of firms, the more unlikely they will be willing to report on environmental issues. In other words, since firms with a high debt-to-equity ratio tends to have difficulties in their long-term solvency; interestingly therefore, they will be unwilling to devote any extra cost on corporate environmental matters and their commitment and compliance level to creating a sustainable environment in which they operate is greatly hampered.

\section{Conclusion and recommendations}

Consistent with finding provided by Markowitz (1972) and Mackinlay (1997), this study observed that there is a significant positive relationship between the financial performance of firms' and the level of corporate social responsibility disclosure. More so, a significant positive association was observed between the size of audit firms and the level of corporate social responsibility disclosures among selected listed firms. However, a significant but negative relationship was observed between firms' financial leverage and the level of environmental disclosures among the selected firms. The paper also observed that there are no existing environmental reporting standards as far as environmental disclosure is concerned in the country. Moreover, there are no mandatory requirements for companies to undergo environmental audit. The paper consequently concludes that given the historical foundation of environmental regulation in Nigeria, it is understandable that sustainable business practice is relatively new in terms of enforceable regulatory principles. Therefore, the paper recommends that since the return on total assets has a positive impact on the extent of environmental disclosure, government as part of their responsibility should put in place policies that will create a good business environment for firms operating in the country. Finally, the paper calls for standard setting bodies to set up environmental reporting framework, in order to improve the level of financial and non-financial environmental disclosures among the listed firms. For future research, it would be remarkable to know if the quality and quantity of environmental disclosures in the same period are identical in order industries not selected.

\section{References}

Abbott, W.F., and Monsen, R.J. (1979). On the Measurement of Corporate Social Responsibility: Self-reported Disclosures as a Method of Measuring Corporate Social Involvement. Academy of Management Journal, Vol. 22, No. 3, pp.501-515. http://dx.doi.org/10.2307/255740 
Abu-Baker, N., and Naser, K. (2000). Empirical Evidence on Corporate Social Disclosure Practices in Jordan. International Journal of Commerce and Management, Vol. 10, No. 3 \& 4, pp.18-34. http://dx.doi.org/10.2307/255740

Ahmad, N. N., Sulaiman M., and Siswantoro, D. (2008). Corporate Social Responsibility Disclosure in Malaysia: an analysis of annual reports of KLSE listed companies. IIUM Journal of Economics and Management, Vol. 11, No.1, pp. 68-76.

Amaeshi, K. M., Adi, B. C., Ogbechie, C., and Amao, O.O. (2006). Corporate Social Responsibility in Nigeria: Western Mimicry or Indigenous Practices? Research Paper Series-ISSN 1479-5124 No. 39-2006, International Centre for Corporate Social Responsibility Nottingham University Business School.

Belal, A.R. (2001). A Study of Corporate Social Disclosures in Bangladesh. Managerial Auditing Journal, Vol. 16, No. 5, pp.274-289. http://dx.doi.org/10.1108/02686900110392922

Coopers, S., and Lybrand E. (1998). Corporate Environmental Reporting: What does it mean for Business? Journal of Accounting and Public Policy, Vol. 3, No. 1, pp.16-22. [Online] Available: http://www.highbeam.environ/global.reporting.ecom (February 11, 2007)

Cowen, S. S., Ferari, L. B., and Parker, L. D. (1987). The impact of corporate characteristics on social responsibility disclosure. Accounting, Organisations and Society, Vol. 2, No. 2, pp.111-122. http://dx.doi.org/10.1108/02686900110392922

Deegan, C., and Rankin, M. (1996). Do Australian Companies Report Environmental News Objectively? An Analysis of Environmental Disclosures By Firms Prosecuted Successfully by the Environmental Protection Authority. Accounting, Auditing and Accountability Journal, Vol. 9, No. 2, pp.50-67. http://dx.doi.org/10.1108/09513579610116358

Dutta, P., and Bose, S (2008). Corporate environmental on the Internet in Bangladesh: An Exploratory Study. International Review of Research Papers, Vol. 4, No. 3, June 2008, pp. 138-150.

Gray, R.H., Kouhy, R., and Lavers, S. (1995). Corporate Social and Environmental Reporting: A Review of the Literature and a longitudinal study of United Kingdom Disclosure. Accounting, Auditing, and Accountability Journal, Vol. 8, No. 2, pp. 47-79. http://dx.doi.org/10.1108/09513579510146996

Gray, R.H., Owen, D., and Adams, C. (1996). Accounting and Accountability: Changes and Challenges in Corporate Social and Environmental Reporting. Hemel Hempstead, Prentice Hall.

Guobadia, A. (2000). Protecting Minority and Public Interests in Nigeria Company Law: The Corporate Affairs Commission as a Corporations Ombudsman, In: F. McMillan (ed.) International Company Law Annual, Vol.1 p. $81-145$.

Guthrie, J., and Parker, L. (1989). Corporate Social Reporting: A Rebuttal of Legitimacy Theory. Accounting and Business Research, Vol. 19, Issue 76, pp.343-352.

Guthrie, J., and Parker, L. (1990). Corporate Social Disclosure Practice: A Comparative International Analysis. Advances in Public Interest Accounting, Vol. 3, pp. 159-175.

Hackston, D., and Milne, M. J. (1996). Some Determinants of Social and Environmental Disclosures in New Zealand companies. Accounting, Auditing and Accountability Journal, Vol. 9, No 1, pp.77-108. http://dx.doi.org/10.1108/09513579610109987

Halme, M., and Huse, M. (1997). The Influence of Corporate Governance, Industry and Country Factors of Environmental Reporting. Scandinavian Journal of Management, Vol. 13, No. 2 pp.137-157. http://dx.doi.org/10.1016/S0956-5221(97)00002-X

Hjalte, S., and Larsson, S. (2003). Communication and Reporting of Corporate Social Responsibility: A study of ABB. Working paper No. 142. [Online] Available: www.samglobal.webmaster.mpi/html (April 21, 2008)

Ite, U. E. (2004). Multinationals and Corporate Social Responsibility in Developing Countries: A Case Study of Nigeria. Corporate Social Responsibility and Environmental Management, Vol. 11, No. 1, pp.1-11. $\mathrm{http}: / / \mathrm{dx}$. doi.org/10.1002/csr.49

Jasch, C. (2003). The use of Environmental Management Accounting for Identifying Environmental Costs. Journal of Cleaner Production, Vol.11, pp.16. http://dx.doi.org/10.1016/S0959-6526(02)00107-5

Krippendorff, K. (1980). Content Analysis: An Introduction to its Methodology. Sage, Beverly Hills, California. 
Li, Lin. (2001). Encouraging Environmental Accounting Worldwide: A Survey of Government Policies and

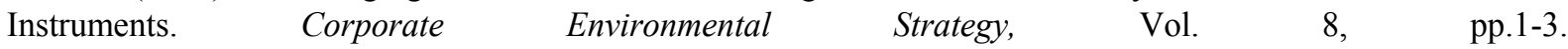
http://dx.doi.org/10.1016/S1066-7938(00)00076-2

Lindbolm, C.K. (1993). The concept of organizational Transition and Transformations: Some Alternative Models. Working paper, Vol. 12, No. 2, America American Accounting Association Public interest section

Milne, M. J., and Adler, R. W. (1999). Exploring the Reliability of Social and Environmental Disclosures Content Analysis. Accounting, Auditing and Accountability Journal, Vol. 12, No. 2, pp.237-256. http://dx.doi.org/10.1016/S1066-7938(00)00076-2

Mohammad, J., and Ahmad, Z. (2001). Determinants of Environmental Reporting in Malaysia, A Positive Accounting Approach. Journal of Accounting Research, Vol. 32, No. 2, 38-60.

Mohammed, J. (1999). Corporate Social Environmental in Malaysia: The Current State of the Art and Future Prospects. Accountant Today, May 2004, pp. 24-31.

Patten, D. M. (2002b). The relation between environmental performance and environmental disclosure: a research note. Accounting, Organizations and Society, Vol. 27, No. 8, pp.763-773. http://dx.doi.org/10.1016/S0361-3682(02)00028-4

Sarumpaet S. (2005). The Relationship between Financial Performance and Environmental of Indonesian Companies. Journal Akuntansi \& keuangan, Vol. 7, No. 2, November 2005: pp. 89-98.

Savage, A.A. (1994). Environmental reporting: Stakeholder's Perspective, Port Elizabeth. University of Port Elizabeth, Working paper 94.

Spicer, B. H. (1978). Investors, Corporate Social Performance and Information Disclosure: An Empirical Study. The Accounting Review, Vol. LIII, No. 1, pp.94-111.

Trotman, K. T., and Bradley, G. W. (1981). Associations between Social Responsibility Disclosure and characteristics of companies. Accounting, Organisations and Society, Vol. 6, No. 4, pp.355-362. http://dx.doi.org/10.1016/0361-3682(81)90014-3

Tsang, E.K. (1998). A longitudinal study of corporate social reporting in Singapore: the case of the banking, food and beverage and hotel industries. Accounting Auditing and Accountability Journal, Vol. 11, No.5, pp.624-635. http://dx.doi.org/10.1108/09513579810239873

Ullmann, A. (1985). Data in Search of a Theory: A Critical Examination of The Relationships among Social Performance, Social Disclosure, and Economic Performance of US firms. Academy of Management Review, Vol. 10, Issue 3, pp.540-557.

United States Environmental Protection Agency. (1995). An Introduction to Environmental Accounting as a Business Management Tool: Key Concepts and Terms, EPA 742-R-95 001 June.

Watts, R. L., and Zimmerman, J. L. (1978). Towards a Positive Theory of the Determination of Accounting Standards. Accounting Review, Vol. 54, No. 2, pp.112-134.

Zadek, S. (1998). Balancing performance, ethic and accountability. Journal of Business Ethics, 17, 1421-1441. http://dx.doi.org/10.1023/A:1006095614267

Table 1. Proxies and predicted signs for explanatory variables

\begin{tabular}{|l|c|c|c|c|}
\hline Variable & $\begin{array}{c}\text { Predicted } \\
\text { Sign }\end{array}$ & Type & Data Type & Scale \\
\hline ROA & + & Independent & Continuous & Return on assets \\
\hline DE & - & Independent & Continuous & Debt to equity ratio \\
\hline AUD & + & Independent & Ordinal & $\begin{array}{c}1=\text { Auditor affiliated with the big four auditing firm. } \\
0=\text { Auditor not affiliated with the big four auditing firm. }\end{array}$ \\
\hline
\end{tabular}


Table 2. Pearson correlations for selected listed firms

\begin{tabular}{|l|l|c|c|c|c|}
\hline & & CSRD & ROTA & D/E & AUD \\
\hline \multirow{5}{*}{ CSRD } & Pearson Correlation & 1 & $.667^{* *}$ & $-.552^{* *}$ & $.423^{* *}$ \\
\cline { 2 - 6 } & Sig. (2-tailed) & & .000 & .000 & .006 \\
\cline { 2 - 6 } & $\mathrm{N}$ & 41 & 41 & 41 & 41 \\
\hline \multirow{5}{*}{ ROTA } & Pearson Correlation & $.667^{* *}$ & 1 & $-.433^{* *}$ & .126 \\
\cline { 2 - 6 } & Sig. (2-tailed) & .000 & & .005 & .433 \\
\cline { 2 - 6 } & $\mathrm{N}$ & 41 & 41 & 41 & 41 \\
\hline \multirow{5}{*}{ D/E } & Pearson Correlation & $-.552^{* *}$ & $-.433^{* *}$ & 1 & -.181 \\
\cline { 2 - 6 } & Sig. (2-tailed) & .000 & .005 & & .257 \\
\cline { 2 - 6 } & $\mathrm{N}$ & 41 & 41 & 41 & 41 \\
\hline & Pearson Correlation & $.423^{* *}$ & .126 & -.181 & 1 \\
\cline { 2 - 6 } & Sig. (2-tailed) & .006 & .433 & .257 & 41 \\
\cline { 2 - 6 } & $\mathrm{N}$ & 41 & 41 & 41 & \\
\hline
\end{tabular}

Note: ${ }^{* *}$ Correlation is significant at the 0.01 level (2-tailed).

Table 3. Model summary

\begin{tabular}{|c|c|c|c|c|c|c|c|c|c|}
\hline \multirow[b]{2}{*}{ Model } & \multirow[b]{2}{*}{$\mathrm{R}$} & \multirow[b]{2}{*}{ R Square } & \multirow[b]{2}{*}{$\begin{array}{l}\text { Adjusted } \\
\text { R Square }\end{array}$} & \multirow[b]{2}{*}{$\begin{array}{l}\text { Std. Error of } \\
\text { the Estimate }\end{array}$} & \multicolumn{5}{|c|}{ Change Statistics } \\
\hline & & & & & $\begin{array}{l}\text { R Square } \\
\text { Change }\end{array}$ & F change & df1 & df2 & Sig. F Change \\
\hline 1 & $.789^{\mathrm{a}}$ & .622 & .592 & 1.69132 & .622 & 20.331 & 3 & 37 & .000 \\
\hline
\end{tabular}

a: Predictors: (Constant), AUD, ROTA, D/E

Table 4. ANOVA ${ }^{\mathrm{b}}$

\begin{tabular}{|c|l|c|c|c|c|c|}
\hline Mode & & Sum of Squares & Df & Mean Square & F & Sig. \\
\hline 1 & Regression & 174.473 & 3 & 58.158 & \multirow{2}{*}{20.331} & \multirow{2}{*}{$.000^{\mathbf{a}}$} \\
\hline & Residual & 105.840 & 37 & 2.861 & & \\
\hline & Total & 280.313 & 40 & & & \\
\hline
\end{tabular}

a: Predictors: (Constant), AUD, ROTA, D/E

b: Dependent Variable: CSRD

Table 5. Coefficients ${ }^{\text {a }}$

\begin{tabular}{|c|c|c|c|c|c|}
\hline \multirow{3}{*}{ Model } & \multicolumn{2}{|c|}{ Unstandardized Coefficients } & Standardized Coefficients & \multirow{2}{*}{ t } & \multirow{2}{*}{ Sig } \\
\cline { 2 - 6 } & $\mathbf{B}$ & Std. Error & Beta & -.385 & .703 \\
\hline $\mathbf{1}$ & -.446 & 1.160 & & 4.531 & .000 \\
\cline { 2 - 6 }$\left(\begin{array}{c}\text { Constant) } \\
\text { ROTA }\end{array}\right.$ & .975 & .215 & .508 & -2.443 & .019 \\
\cline { 2 - 6 } D/E & -.356 & .146 & -.276 & & \\
AUD & 2.285 & .761 & .309 & 3.002 & .005 \\
\hline
\end{tabular}

a: Dependent Variable: CSRD 
Table 6. List of selected listed firms for the study

\begin{tabular}{|c|c|c|}
\hline $\mathbf{S} / \mathbf{N}$ & BANKS & TYPE \\
\hline 1 & Fedility Bank & \multirow{17}{*}{ FINANCIAL } \\
\hline 2 & Access Bank plc & \\
\hline 3 & First bank of Nigeria plc & \\
\hline 4 & Ecobank Nigeria plc & \\
\hline 5 & Firstinland Bank plc & \\
\hline 6 & Guaranty Trust Bank plc & \\
\hline 7 & Oceanic Bank International plc & \\
\hline 8 & Skye Bank plc & \\
\hline 9 & First City Monument Bank plc & \\
\hline 10 & PlatinumHabib Bank plc & \\
\hline 11 & Diamond Bank plc & \\
\hline 12 & Union Bank of Nigeria plc & \\
\hline 13 & United Bank for Africa plc & \\
\hline 14 & Spring Bank plc & \\
\hline 15 & Stanbic IBTC bank plc & \\
\hline 16 & Sterling Bank plc & \\
\hline 17 & Zenith Bank plc & \\
\hline 18 & Benue Cement Company plc & \multirow{24}{*}{$\begin{array}{c}\text { NON-FINANCIAL } \\
\text { FIRMS }\end{array}$} \\
\hline 19 & Lafarge West African Portland Cement plc & \\
\hline 20 & Cement Company of Northern (Nigeria) plc & \\
\hline 21 & Ceramic Manufacturers Nigeria plc & \\
\hline 22 & African Paints (Nigeria) plc & \\
\hline 23 & Berger Paints plc & \\
\hline 24 & Chemical \& Allied Products plc & \\
\hline 25 & DN Meyer plc & \\
\hline 26 & Nigerian - German chemical plc & \\
\hline 27 & Okitipupa Oil Palm plc & \\
\hline 28 & Presco plc & \\
\hline 29 & Okomu Oil Palm plc & \\
\hline 30 & Ellah - lakes plc & \\
\hline 31 & Livestock Feeds plc & \\
\hline 32 & Guinness Nigeria plc & \\
\hline 33 & Nigerian Breweries plc & \\
\hline 34 & Jos International Breweries plc & \\
\hline 35 & Champion Breweries plc & \\
\hline 36 & International Breweries plc & \\
\hline 37 & African Petroleum plc & \\
\hline 38 & Chevron Oil Nigeria plc & \\
\hline 39 & Mobile Oil Nigeria plc & \\
\hline 40 & Oando plc & \\
\hline 41 & Total Nigeria plc & \\
\hline
\end{tabular}


Table 7. Twenty eight testable environmental disclosure items study

\begin{tabular}{|c|c|c|c|c|}
\hline $\mathbf{S} / \mathbf{N}$ & Environment & Energy & $\begin{array}{l}\text { Research \& } \\
\text { Development }\end{array}$ & Employee Health and Safety \\
\hline 1 & $\begin{array}{l}\text { Environmental } \\
\text { pollution }\end{array}$ & firms energy policies & $\begin{array}{l}\text { Investment in research on } \\
\text { renewal technology }\end{array}$ & Disclosing accident statistics. \\
\hline 2 & $\begin{array}{l}\text { Conservation of } \\
\text { natural } \\
\text { resources }\end{array}$ & $\begin{array}{l}\text { Disclosing energy } \\
\text { savings }\end{array}$ & Environmental education & $\begin{array}{l}\text { Reducing or eliminating } \\
\text { pollutants, irritants, or hazards } \\
\text { in the work environment. }\end{array}$ \\
\hline 3 & $\begin{array}{l}\text { Environmental } \\
\text { management }\end{array}$ & $\begin{array}{l}\text { Reduction in } \\
\text { energy } \\
\text { Consumption }\end{array}$ & Environmental research. & $\begin{array}{l}\text { Promoting employee safety and } \\
\text { physical or mental health }\end{array}$ \\
\hline 4 & $\begin{array}{l}\text { Recycling plant } \\
\text { of waste } \\
\text { products }\end{array}$ & $\begin{array}{l}\text { Received awards or } \\
\text { penalties. }\end{array}$ & $\begin{array}{l}\text { Waste management } \\
\text { /reduction and recycling } \\
\text { technology }\end{array}$ & $\begin{array}{l}\text { Disclosing benefits from } \\
\text { increased health and safety } \\
\text { expenditure. }\end{array}$ \\
\hline 5 & $\begin{array}{l}\text { Air emission } \\
\text { information }\end{array}$ & $\begin{array}{l}\text { Disclosing increased } \\
\text { energy } \\
\text { efficiency products }\end{array}$ & $\begin{array}{l}\text { Research on new method } \\
\text { of production }\end{array}$ & $\begin{array}{l}\text { Complying with health and } \\
\text { safety standards and regulations. }\end{array}$ \\
\hline 6 & $\begin{array}{l}\text { Environmental } \\
\text { policies or } \\
\text { company } \\
\text { concern for the } \\
\text { environment }\end{array}$ & $\begin{array}{l}\text { Conservation of } \\
\text { energy in the } \\
\text { conduct of business } \\
\text { operations }\end{array}$ & $\begin{array}{l}\text { Providing information for } \\
\text { conducting safety research } \\
\text { on the company's products }\end{array}$ & Health and Safety Arrangements \\
\hline 7 & $\begin{array}{l}\text { Installation of } \\
\text { effluent } \\
\text { treatment plant }\end{array}$ & $\begin{array}{l}\text { Discussion of the } \\
\text { company's efforts to } \\
\text { reduce energy } \\
\text { Consumption }\end{array}$ & $\begin{array}{l}\text { Information on research } \\
\text { projects set up by the } \\
\text { company to improve its } \\
\text { product in any way }\end{array}$ & $\begin{array}{l}\text { Establishment of Educational } \\
\text { Institution }\end{array}$ \\
\hline
\end{tabular}

Source: Ernst and Ernst, 1978; Sulaiman and Siswantoro, 2003; Gray et al, 1995; Hackston and Milne, 1996; Milne and Adler, 1999; Tilt, 2000 